\title{
TEORI BELAJAR HUMANISTIK ABRAHAM MASLOW \\ DAN CARL ROGERS SERTA IMPLIKASINYA DALAM \\ PEMBELAJARAN PENDIDIKAN AGAMA ISLAM
}

\author{
Farah Dina Insani \\ 19204010033@student.uin-suka.ac.id \\ UIN Sunan Kalijaga Yogyakarta
}

\begin{abstract}
This article aims to describe the humanistic learning theory and its implications for learning Islamic Religious Education. Collecting research data using the documentation method, whether in technique, data in library research (library research). The object of study is an article that focuses on Abraham Maslow and Carl Rogers' Humanistic learning theory and its implementation in Islamic Education learning. The results of this study indicate that humanistic learning theory is a learning process that originates and ends in humans, everything rests on human values. The humanistic education system approach emphasizes the development of human dignity who makes choices and has beliefs. Learning is considered significant, if the learning material has relevance to student needs. Students who act as the main actors interpret the process of their own learning experience. The expected positive impact of this article is the appreciation of the wider community about the importance of humanizing humans in learning activities to achieve self-actualization of students.
\end{abstract}

\section{Keywords: Humanistic, PAI, Abraham Maslow, Carl Rogers}

\begin{abstract}
Abstrak
Artikel ini bertujuan untuk mendeskripsikan teori pembelajaran humanistik dan implikasinya terhadap pembelajaran Pendidikan Agama Islam. Pengumpulan data penelitian ini menggunakan metode dokumentasi, sebagaimana dalam teknik pengumpulan data pada penelitian kepustakaan (library research). Objek kajian pada artikel ini terfokuskan pada teori belajar Humanistik Abraham Maslow dan Carl Rogers serta implementasinya dalam pembelajaran PAI. Hasil penelitian ini menunjukkan bahwa Teori pembelajaran humanistik merupakan sebuah proses belajar yang berhulu dan bermuara pada manusia, segala sesuatunya disandarkan pada nilai kemanusiaan. Pendekatan sistem pendidikan humanistik menekankan pengembangan martabat manusia yang bebas membuat pilihan dan berkeyakinan. Belajar dipandang signifikan, jika materi pembelajaran memiliki relevansi dengan kebutuhan siswa. Siswa berperan sebagai
\end{abstract}


pelaku utama yang memaknai proses pengalaman belajarnya sendiri. Dampak positif yang diharapkan dari artikel ini ialah teredukasinya masyarakat luas tentang pentingnya memanusiakan manusia dalam kegiatan pembelajaran untuk mencapai aktualisasi diri peserta didik.

\section{Kata Kunci: Humanistik, PAI, Abraham Maslow, Carl Rogers}

\section{A. Pendahuluan}

Belajar adalah suatu proses perubahan didalam kepribadian manusia, dan perubahan tersebut tampak dalam bentuk peningkatan kualitas dan kuantitas tingkah laku seperti peningkatan kecakapan, pengetahuan, sikap, kebiasaan, pemahaman, ketrampilan, daya pikir dan kemampuan lainnya. ${ }^{1}$ Teori-teori tentang belajar dan pembelajaran tersebut sangat perlu diketahui dan dipahami oleh para pendidik maupun calon pendidik, agar mereka mampu memahami bagaimana proses belajar dan pembelajaran yang baik, sehingga mereka dapat mendidik para peserta didik dengan baik. Secara umum berdasarkan orientasinya teori tentang belajar dan pembelajaran diklasifikasikan menjadi empat yang meliputi teori belajar kognitif, teori belajar behavioristik, teori belajar humanistik, teori belajar sosial dan lain-lain. ${ }^{2}$

Pada artikel ini akan dibahas salah satu dari teori-teori tersebut yaitu teori humanistik. Teori ini mempelajari perilaku belajar peserta didik dan mengembangkan potensi yang ada di dalam dirinya. Sebagai salah satu teori belajar yang sangat relevan untuk diterapkan pada saat sekarang ini tentu saja pembahasan lebih mendalam mengenai pengertian, tokoh, prinsip, implikasi, dan aplikasi dari teori humanistik ini sangat urgen keberadaannya untuk dibahas lebih lanjut melalui penelitian.

Penelitian ini menggunakan metode pengumpulan data dokumentasi, sebagaimana yang ada dalam teknik pengumpulan data pada penelitian kepustakaan (library research). Metode dokumentasi adalah metode yang dilakukan oleh peneliti terhadap benda-benda atau dokumen-dokumen seperti majalah, buku-buku, notulen rapat catatan harian dan sebagainya.

1 Thunsan Hakim, Belajar Secara Efektif, (Yogyakarta : Niaga Sadaya), hlm. 1.

2 Aunurrahman, Jurnal Pendidikan konvergensi edisi juli 2018, hlm. 71. 
Adapun teknik pengumpulan data yang digunakan penulis adalah mengumpulkan sumber-sumber primer maupun skunder berupa buku yang ada kaitannya dengan tema pembahasan pada artikel ini. Penelitian ini bertujuan untuk mendapatkan data dan penjelasan mengenai pembahasan tema artikel secara terperinci.

\section{B. Pembahasan}

\section{A. Konsep Dasar Teori Belajar Humanistik}

Psikologi humanisme merupakan aliran psikologi yang berlandaskan pada eksistensiamisme yaitu paham yang menolak menempatkan manusia semata-mata sebagai hasil hereditas atau lingkungan. Aliran ini menganggap bahwa setiap individu memiliki kebebasan untuk memilih tindakan, menentukan sendiri nasib atau eksistensinya itu. ${ }^{3}$

Teori belajar humanistik merupakan salah satu teori belajar yang paling abstrak diantara teori belajar yang ada, karena teori ini lebih banyak membicarakan gagasa tentang belajar yang paling ideal dari pada memperhatikan apa yang bisa dilakukan dalam keseharian. Teori belajar humanistik memiliki tujuan untuk memanusiakan manusia. Belajar dalam teori humanistik dikatakan berhasil jika peserta didik bisa memahami lingkungan dan dirinya sendiri (mencapai aktualisasi diri). ${ }^{4}$

Berbeda dengan teori belajar behavioristik dan teori belajar kognitif, yang terpenting dari teori belajar humanistik adalah menekankan pada kehidupan kejiwaan manusia, di dalamnya terdapat potensi-potensi manusia yang khas dan istimewa yang perlu diselami atau diberdayakan. ${ }^{5}$

Teori humanistik lebih mengedepankan sisi humanis manusia dan tidak menuntut jangka waktu pembelajar mencapai pemahaman yang diinginkan, akan tetapi lebih menekankan pada isi atau materi yang harus

${ }^{3}$ Lefudin, Belajar Dan Pembelajaran Dilengkapi dengan Model Pembelajaran, Strategi Pembelajaran, Pendekatan Pembelajaran dan Metode Pembelajaran, (Yogyakarta : Deepublish, 2014), hlm. 12.

${ }^{4}$ Andi Setiawan, Belajar dan Pembelajaran, (Ponorogo : Uwais Inspirasi Indonesia), hlm.

${ }^{5}$ Husama dkk, Belajar dan Pembelajaran, (Malang : UMM Press, 2018), hlm. 115. 
dipelajari agar membentuk manusia seutuhnya. Proses belajar dilakukan agar pembelajar mendapatkan makna yang sesungguhnya dari belajar atau yang disebut Ausubel sebagai meaningful learning. Meaningful learning bermakna bahawa belajar adalah mengasosiasikan pengetahuan baru dengan prior knowledge (pengetahuan awal) si pembelajar. Setiap pembelajar memiliki kecepatan belajar yang berbeda-beda sehingga keberhasilan belajar akan tercapai apabila pembelajar dapat memahami diri dan lingkungannya. Hal ini karena setiap manusia adalah unik dan tugas pendidik adalah membantu mengenali sisi unik tersebut serta mewujudkan potensi yang dimiliki oleh siswa. ${ }^{6}$

\section{B. Pendapat Para Tokoh Tentang Teori Belajar Humanistik}

Dalam teori belajar humanistik ini banyak tokoh yang membahas tentang teori ini namun dalam artikel ini penulis hanya membahas dua tokoh saja yaitu Abraham Maslow dan Carl Rogers.

\section{Abraham Maslow}

\section{a. Biografi singkat Abraham Maslow}

Abraham Maslow (lahir 1 April 1908 - meninggal 8 Juni 1970 pada umur 62 tahun) adalah teoretikus yang banyak memberi inspirasi dalam teori kepribadian. Ia juga seorang psikolog yang berasal dari Amerika dan menjadi seorang pelopor aliran psikologi humanistik.

Pada masa kanak-kanak Abraham Maslow merupakan satu-satunya anak laki-laki yahudi di sebuha perkampuan non-yahudi dipinggiran kota Brooklyn. Begitu remaja Maslow berangkamatang mulailah ia mengagumi karya-karya para filsof seperti Alfred North, Whitehead, Henri Bargson, Thomas Jefferson, Abraham Lincolin, Plato dan Spinoza. ${ }^{7}$

${ }^{6}$ Jamil Suprihatiningrum, Strategi Pembelajaran: Teori dan Aplikasi, (Yogyakarta: Ar-Ruzz Media, 2013), hlm. 31-32.

7 Supratinya, Mazhab Ketiga Psikologi Abraham Maslow Oleh Frank G. Goble, (Yogyakarta : Kanisius, 2010), hlm. 28. 
Ia menikah di usia muda, setelah menikah dia melanjutkan belajar Wisconsin dan berjumpa dengan J.B Watson dan ia segera jatuh cinta dengan behaviorisme. Namun setelah bacannya tentang psikologi Gestalt dan psikologi Freudian semakin luas, antusiasnya pada behaviorisme menurun. ${ }^{8}$ Banyak buku-buku yang ditulis oleh Maslow seperti Motivation and Personality, Toward a Psychology of Being. ${ }^{9}$

\section{b. Pemikiran Abraham Maslow tentang teori belajar humanistik}

Abraham maslow mengemukakan bahwa seseorang berperilaku pada dasarnya ditujukan untuk memenuhi kebutuhan yang bersifat hirarkis. Abraham Maslow merupakan salah satu pelopor aliran humanistik. Abraham Maslow merupakan salah satu pelopor aliran humanistik. Maslow percaya bahwa manusia begerak untuk memahami dan menerima dirinya sebisa mungkin. Teori yang sangat terkenal adalah teori hirarki kebutuhan Maslow. Maslow menjelaskan bahwa manusia termotivasi untuk memenuhi kebutuahan kebutuhan hidupnya. Kebutuhan tersebut bertingkat dari yang paling rendah (bersifat dasar/ fisiologi) sampai dengan yang tertinggi (aktualisasi diri). ${ }^{10}$

Dalam perspektif humanistik (humanistic perspective) menuntut potensi peserta didik dalam proses tumbuh kembang, kebebasan menemukan jalan hidupnya. ${ }^{11}$ Dalam prospektif humanistik menuntut potensi peserta didik dalam proses tumbuh kembang bebas dalam menemukan jalan hidupnya. ${ }^{12}$ Humanistic menganggap peserta didik sebagai subjek yang merdeka guna menetapkan tujuan hidup dirinya. Peserta didik dituntun agar memiliki sifat tanggung jawab terhadap kehidupannya dan orang di

8 Ibid, hlm. 30.

9 Ibid, hlm. 32.

10 Andi Setiawan, Belajar dan Pembelajaran......, hlm. 89.

${ }^{11}$ Iskandar, Implementasi Teori Hirarki Kebutuhan Abraham Maslow TerhadapPeningkatan Kinerja Pustakawan, Vol. 4 No. 1, Januari -Juni 2016, hlm. 27.

12 Jhon W. Santrock, Psikologi Pendidikan (Jakarta: Salemba Humanika, 2009), hlm. 201. 
sekitarnya. ${ }^{13}$

\section{c. Hirarki kebutuhan menurut Abraham Maslow}

Adapun hirarki kebutuhan tersebut adalah sebagai berikut :

1) Kebutuhan fisiologi / dasar seperti makan dan minum

2) Kebutuhan akan rasa aman nyaman dan tentram seperti terhindar dari kriminalitas, binatang buas, diejek direndahkan dll

3) Kebutuhan untuk dicintai dan disayangi seperti bagaimana rasannya dianggap dikomunitas sosialnya

4) Kebutuhan untuk dihargai seperti rasa bagaimana dibutuhkan untuk kepercayaan dan tanggung jawab dari orang lain

5) Kebutuhan aktualisasi diri untuk membuktikan dan menunjukkan dirinya terhadap orang lain. ${ }^{14}$

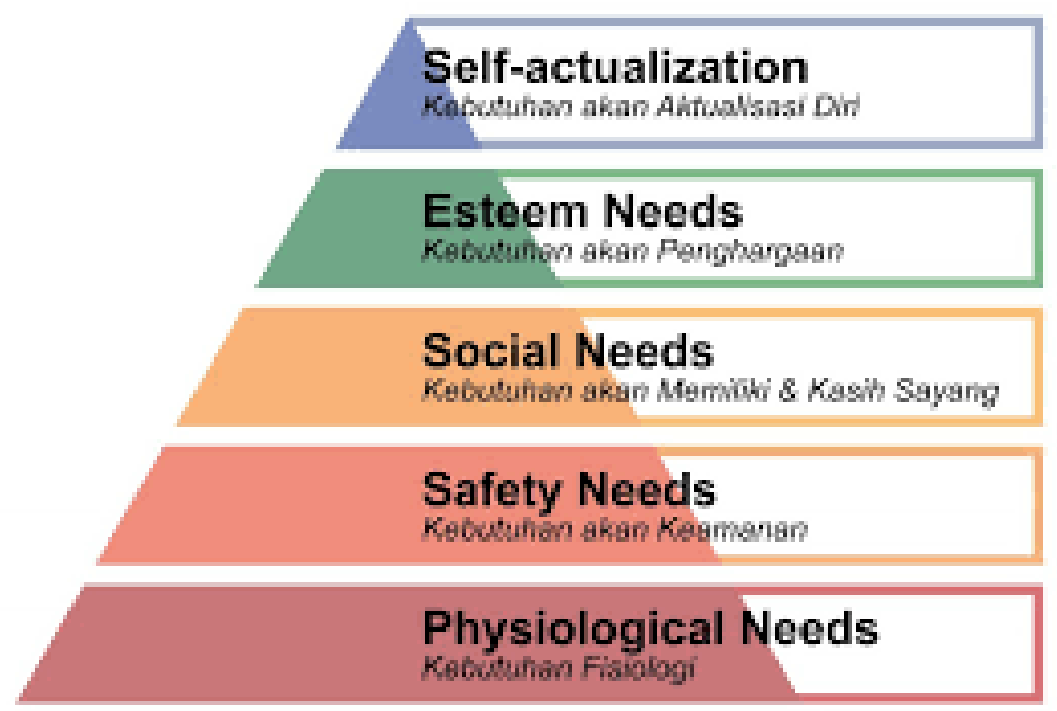

Dalam reverensi lain menjelaskan bahwa inti dari teori Maslow adalah bahwa kebutuhan tersusun dalam suatu hirarki. Kebutuhan di tingkat yang paling rendah adalah kebutuhan fisiologi dan kebutuhan ditingkat yang paling tinggi adalah kebutuhan aktualisasi diri. Maslow mengasumsikan bahwa orang yang berusaha memuaskan kebutuhan yang mendasar (kebutuhan fisiologi) sebelum

13 Arbayah, Model Pembelajaran Humanistik, Vol 13. No. 2, Desember 2013, hlm. 215.

14 Ibid, hlm. 89. 
mengarahkan perilaku mereka pada pemuasan kebutuahan ditingkat yang lebih tinggi. ${ }^{15}$ Beberapa hal pokok dalam pemikiran Maslow penting kita ketahui untuk memahami pendekatan hirarki kebutuhan.

1) Kebutuhan yang sudah terpuaskan akan berhenti memberikan motivasi. Sebagai contoh, ketika seseorang menganggap dirinya telah mendapatkan imbalan yang cukup karena telah memberikan kontribusi kepada organisasi, upah kehilangan kekuatannya dalam memberikan motivasi.

2) Kebutuhan yang tidak terpuaskan dapat menyebabkan rasa frustasi, konflik dan strees. Dari perspektif menejerial, kebutuhan yang tidak terpuaskan akan berbahaya karena kebutuhan ini menyebabkan hasil kinerja yang tidak diinginkan.

3) Maslow mengasumsikan bahwa orang memiliki kebutuahan untuk tumbuh dan berkembang sebagai akibat, akan terus berkembang dan bergerak ke atas dalam hirarki untuk memenuhi kepuasan. Asumsi ini mungkin benar untuk beberapa orang dan tidak untuk sebagian yang lain. ${ }^{16}$

\section{d. Implikasi teori belajar humanistik Abraham Maslow dalam pembelajaran PAI}

Adapun implikasi teori belajar humanistik dalam pemebelajaran PAI adalah sebagai berikut : ${ }^{17}$

1) Memenuhi kebutuhan fisiologis ialah kebutuhan makan dan minum, pakaian, tempat tinggal, termasuk kebutuhan biologis. yang merupakan kebutuhan paling dasar karena dibutuhkan semua makhluk hidup. Pemenuhan kebutuhan dasar peserta didik harus di utamakan karena kebutuhan ini sangat mendesak dan hendaknya guru memberikan kesempatan atau bantuan

15 Ivancevich dkk, Perilaku dan Manajemen Organisasi, (Semarang : Erlangga, 2006), hlm. 148.

16 Ibid, hlm. 149.

17 Budi Agus Sumantri dan Nurul Ahmad, Teori Belajar Humanistik dan Implikasinya Terhadap Pembelajaran Pendidikan Agama Islam, Jurnal, Volume 3 Nomor 2 September 2019, hlm. 10-11. 
kepada siswa untuk memenuhinya. Dalam pembelajaran PAI sebelum memutuskan cara pembelajaran apa yang pantas diterapkan pada pembelajaran PAI, hendaknya para pendidik mengetahui terlebih dahulu keterlibatan kebutuhankebutuhan yang menjadi dasar motivasi dalam mencapai tujuan pembelajaran PAI Mengakomondasi kebutuhan rasa aman secara fisik maupun psikis.

2) Mengakomondasi kebutuhan rasa aman secara fisik maupun psikis. Aman secara fisik, seperti terhindar dari kriminalisasi, teror, binatang buas, orang lain, tempat yang kurang aman dan sebagainya. sedangkan Aman secara psikis, seperti tidak di marah, tidak dibuly, tidak direndahkan, tidak dipindahkan tanpa keterangan, diturunkan pangkatnya dan sebagainya. Kebutuhan akan keamanan di kelas menjadi tanggung jawab guru. Tugas guru ialah menetapkan peraturan dan jaminan atas keselamatan siswa serta kenyamanan kelas.

3) Kebutuhan sosial dibutuhkan seseorang supaya ia dianggap sebagai warga komunitas sosialnya. Bagi seorang siswa agar bisa belajar dengan baik, ia harus merasa diterima dengan baik oleh teman-temannya. Terkait dengan kebutuhan sosial siswa, guru hendaknya memberikan perhatian supaya siswa mampu berinteraksi dengan baik dan mempunyai rasa saling memiliki terhadap teman-temannya serta lingkungan sekelilingnya.

4) Kebutuhan ego termasuk juga keinginan untuk mendapatkan prestasi dan memiliki wibawa. Seseorang membutuhkan sebuah kepercayaan serta tanggung jawab dari orang lain. Dalam pembelajaran, dengan memberikan tugas-tugas yang menantang maka siswa akan terpenuhi egonya. Prestasi siswa sekecil apapun perlu diberikan apresiasi. Memberikan sebuah penghargaan pada peserta didik mampu memotivasi siswa untuk meningkatkan prestasinya.. 
5) Kebutuhan aktualisasi merupakan kebutuhan untuk menunjukkan dan membuktikan dirinya pada orang lain. Pada tahapan ini seseorang akan mengembangkan semaksimal mungkin potensi yang mereka miliki. Untuk mengaktualisasikan dirinya peserta didik perlu suasana dan lingkungan yang kondusif. Ketika peserta didik sudah di tahap aktualisasi diri,guru hanya tinggal memberikan fasilitas yang diperlukan untuk mengembangkan dirinya secara lebih jauh. Abraham Maslow dengan teori motivasinya mengorieantasikan manusia sebagai subjek yang dapat mengembangkan potensi-potensi yang dimilikinya untuk kemudian dapat mengaktualisasikan diri sebagai manusia yang utuh. Konsep ini sejalan dengan tujuan ajaran Agama Islam yang selalu mengedepankan nilai-nilai agama sebagai landasan motivasi untuk berbuat. Salah satunya menjalankan kewajiban khilafah di muka bumi.

\section{Carl Rogers}

\section{a. Biografi singkat Carl Regors}

Rogers dilahirkan pada tanggal 8 Januari, 1902, di Oakpark, Illinois, pinggiran kota Chicago. Ayahnya, Walter A. Rogers, seorang pekerja teknik sipil dan ibunya, Julia M. Cushing, seorang ibu rumah tangga dan seorang Kristen Pentakostal yang setia. Carl adalah anak keempat dari enam bersaudara.

Rogers merupakan seorang yang cerdas dan dapat membaca dengan baik sebelum menginjak TK. Dengan pendidikannya yang sangat ketat secara religius serta lingkungannya sebagai anak altar di rumah pendeat Jimpley, ia menjadi orang yang terisolasi, independen, disiplin, dan mendapatkan pengetahuan serta apresiasi dari metode ilmiah di dunia praktis. Pilihan pertama kariernya adalah agrikultur, di Universitas Wisconsin-Madison, di mana ia menjadi bagian dari persaudaraan Alpha Kappa Lambda, diikuti dengan sejarah, lalu agama. Pada usia yang ke-20, saat perjalannya ke 
Peking, Cina tahun 1922, untuk mengikuti konferensi internasional Kristen, ia mulai meragukan keyakinan agamanya. Untuk menolongnya memperjelas dalam memilih karier, ia mengikuti sebuah seminar yang bertemakan "Mengapa Saya Memasuki Pelayanan?", yang kemudian membuatnya mengubah kariernya. Tahun 1924, ia lulus dari Universitas Wisconsin dan mendaftar ke Union Theological Seminary.

Setelah dua tahun lulus dari seminari, ia pergi ke Teachers College, Columbia University, mendapatkan gelar M.A. pada tahun 1928 dan Ph.D pada tahun 1931. Sementara ia menyelesaikan pekerjaan doktoralnya, ia terlibat dalam studi tentang anak. Tahun 1930, Rogers bekerja sebagai direktur Society for the Prevention of Cruelty to Children di Rochester, New York. Dari tahun 1935-1940 ia mengajar di University of Rochester dan menulis The Clinical Treatment of the Problem Child (1938), yang berdasarkan pengalamannya saat bekerja dengan anak-anak bermasalah. Dalam mengkonstruksi pendekatan client-centered, ia sangat dipengaruhi oleh praktik psikoterapi post-Fruedian dari Otto Rank. Tahun 1940, Rogers menjadi profesor psikologi klinis di Ohio State University, di mana ia menuliskan buku keduanya, Counseling and Psychotherapy (1942). Di buku itu, Rogers menyarankan bahwa klien, dengan membangun relasi yang berdasarkan pemahaman, penerimaan dari terapis, dapat menyelesaikan berbagai kesulitan dan mendapatkan pencerahan (insight) yang dibutuhkan untuk merekonstruksi hidup mereka.

Tahun 1945, ia diundang untuk mendirikan pusat konseling di University of Chicago. Tahun 1947, ia terpilih menjadi presiden dari American Psychological Association. Sementara ia menjadi profesor psikologi di University of Chicago (1945-1957), Rogers membantu mendirikan pusat konseling yang berhubungan dengan universitas dan di sana ia melakukan riset untuk menentukan 
keefektifan metodenya. Penemuan-penemuan dan teori-teorinya muncul di dalam buku Client-Centered Therapy (1951) dan Psychotherapy and Personality Change (1954). Seorang mahasiswa S-2 binaannya di University of Chicago, Thomas Gordon, mendirikan gerakan Parent Effectiveness Training (P.E.T). Tahun 1956, Rogers menjadi presiden pertama American Academy of Psychotherapists. Ia mengajar psikologi di University of Wisconsin, Madison (1957-1963), yang juga pada saat itu, ia menuliskan bukunya yang terkenal, On Becoming a Person (1961). Carl Rogers dan Abraham Maslow (1908-1970) menjadi pionir gerakan psikologi humanistik yang mencapi puncaknya tahun 1960-an. Pada tahun 1961, ia dipilih sebagai anggota American Academy of Arts and Sciences

\section{b. Pemikiran Carl Regors tentang teori belajar humanistik}

Menurut Rogers semua manusia lahir membawa dorongan untuk meraih sepenuhnya apa yang diinginkan dan berperilaku secara konsisten menurut diri mereka sendiri. Rogers seorang psikoterapis, mengembangkan person-centered therapy. Pendekatan ini tidak bersifat menilai atau tidak memberi arahan yang membuat klien mengklarifikasi dirinya tentang siapa dirinya sebagai suatu upaya memfasilitasi proses memperbaiki kondisinya. Hampir pada saat yang bersamaan, Maslow mengemukakan teorinya bahwa semua orang memiliki motivasi untuk memenuhi kebutuhan yang bersifat hirarki. Rogers terkenal sebagai seorang tokoh psikologi humanis, aliran fenomenologis-eksistensial, psikologis klinis dan terapis. ${ }^{18}$

Rogers merupakan seorang psikologi humanistik yang mementingkan perlunya sikap saling menghargai dan tanpa prasangka dalam membantu individu mengatasi masalah-masalah

${ }^{18}$ Husama dkk, Belajar dan Pembelajaran......, hlm. 116. 
kehidupannya. ${ }^{19}$ Rogers berpendapat bahwa peserta didik yang belajar hendaknya tidak dipaksa akan tetapi mereka dibiarkan untuk belajar bebas, peserta didik harapannya dapat megambil keputusan sendiri dan bertanggung jawab atas pilihannya. Rogers mengemukakan lima hal penting dalam proses belajar humanistik yaitu :

1) Hasrat untuk belajar, hasrat untuk belajar disebabkan adanya hasrat ingin yahu manusia yang terus menerus terhadap dunia sekelilingnya

2) Belajar bermakna, peserta didik yang belajar memilih apakah kegiatan yang dilakukan bermanfaat untuk dirinya atau tidak

3) Belajar tanpa hukuman, belajar yang terbebas dari ancaman hukuman yang menyebabkan anak bebas berekspresi sehingga mereka mampu bereksperimen hingga menemukan sesuatu yang baru

4) Belajar dengan inisiatif sendiri, menyiratkan tingginya motivasi belajar instrinsik yang dimiliki peserta didik yang banyak berinisiatif mampu mengarahkan dirinya sendiri, menentukan pilihannya sendiri serta berusaha menimbang sendiri hal yang baik bagi dirinnya

5) Belajar dan perubahan, peserta didik harus belajar untuk dapat menghadapi kondisi dan situasi yang terus berubah. ${ }^{20}$

Menurut Rogers proses belajar adalah membantu peserta didik agar ia sanggup mencapai perwujudan dirinya (self realization) sesuai dengan kemampuan dasar dan keunikan yang dimiliki peserta didik. Rogers juga menyebutkan bahwa kebermaknaan pembelajaran (significant learning) itu sangat berpengaruh terhadap proses belajar. Belajar signifikan terjadi ketika belajar dirasakan relevan terhadap kebutuhan dan tujuan siswa. Selain itu, Rogers juga mengatakan

19 Andi Setiawan, Belajar dan Pembelajaran......, hlm. 86.

${ }^{20}$ Ibid, hlm. 88. 
bahwa setiap manusia mempunyai potensi belajar secara alami. Dengan demikian, ada keinginan untuk belajar (the desire to learn). Hal ini bisa dilihat dari keingintahuannya anak ketika ingin menjelajahi lingkungannya, berusaha untuk menemukan dan memahami pengetahuan dari pengalaman. ${ }^{21}$

Teori humanistik Rogers lebih penuh harapan dan optimis tentang manusia karena manusia mempunyai potensi-potensi yang sehat untuk maju. Dasar teori ini sesuai dengan pengertian humanisme pada umumnya, di mana humanisme adalah doktrin, sikap, dan cara hidup yang menempatkan nilai-nilai manusia sebagai pusat dan menekankan pada kehormatan, harga diri, dan kapasitas untuk merealisasikan diri untuk maksud tertentu, yang nantinya akan dihubungkan dengan pembelajaran atau pendidikan yang manusiawi. ${ }^{22}$

c. Implikasi teori belajar humanistik Carl Rogers dalam pembelajaran PAI

Segi implikasi ini meliputi penerapan teori belajar humanistic dalam proses pembelajaran. Para ahli psikologi humanistic berupaya menggambarkan keterampilan dan informasi kognitif dengan segi-segi afektif, nilai-nilai, dan perilaku antar pribadi. Contohnya, didalam kelas sudah mendapatkan ilmu melalui teori teori yang di sampaikan oleh guru dan di luar kelas anak-anak mempraktekkan apa yang telah di dapat di dalam kelas pada pertemuan sebelumnya. Karena pada dasrnya pembelajaran PAI bukanlah hanya teori di kelas semata namun harus dengan praktek dan evaluasi kekurangannya dari teori yang sudah di sampaikan di dalam kelas. Maka dari itu sebagai guru PAI harus kreatif dan inovatif agar anak

${ }^{21}$ Sri Esti Wuryani Djiwandono, Psikologi Pendidikan, (Jakarta: PT. Gramedia Widiasarana Indonesia, 2006), hlm. 183.

${ }^{22}$ Khusnul Mualim, Gagasan Pemikiran Humanistik dalam Pendidikan (Perbandingan Pemikiran Naquib al-Attas Dengan Paulo Freire), Jurnal, Universitas Muhammadiyah Yogyakarta. Al-ASASIYYA: Journal Of Basic Education Vol. 01 No. 02Januari-Juni 2017ISSN: 2548-9992. 
tidak merasa bosan karena sudah di sampaikan teori mengapa harus praktek pula.

\section{Prinsip Dasar Teori Belajar Humanistik}

Adapun prinsip dasar dari pendekatan humanistik adalah sebagai berikut :

1. Siswa akan belajar dengan baik apa yang mereka mau dan perlu diketahui.

2. Mengetahui bagaimana cara belajar lebih penting dari pada membutuhkan banyak pengetahuan.

3. Evaluasi diri adalah evaluasi yang berarti untuk pekerjaan siswa.

4. Perasaan adalah sama penting dengan kenyataan.

5. Siswa akan belajar dengan lebih baik dalam lingkungan yang tidak mengancam. ${ }^{23}$

Dalam referensi lain dijelaskan bahwa prinsip-prinsip teori belajar humanistik disajikan sebagai berikut :

1. Siswa harus dapat memilih apa yang mereka ingin pelajari. Guru yang menggunakan teori belajar humanistik percaya bahwa siswa akan termotivasi untuk mengkaji materi bahan ajar jika terkait dengan kebutuhan dan keinginannya.

2. Tujuan pendidikan harus mendorong keinginan siswa untuk belajar dan mengajar mereka tentang cara belajar. Siswa harus memotivasi dan merangsang diri pribadi untuk belajar sendiri.

3. Pendidik Humanistik percaya bahwa nilai tidak relevan dan hanya evaluasi diri (self evaluation) yang bermakna. Pemeringkatan mendorong siswa belajar untuk mencapai tingkat tertentu, bukan untuk kepuasan pribadi. Selain itu, pendidik humanistik menentang tes objektif, karena mereka menguji kemampuan siswa untuk menghafal dan tidak memberi umpan balik pendidikan yang cukup kepada guru dan siswa.

4. Pendidik Humanistik percaya bahwa, baik perasaan maupun pengetahuan, sangat penting dalam proses belajar dan tidak memisahkan domain kognitif dan afektif.

${ }^{23}$ Husama dkk, Belajar dan Pembelajaran ......, hlm. 119. 
5. Pendidik Humanistik menekankan perlunya siswa terhindar dari tekanan lingkungan, sehingga mereka akan merasa aman untuk belajar. Setelah siswa merasa aman, belajar mereka menjadi lebih mudah dan lebih bermakna. $^{24}$

\section{Kelebihan dan Kekurangan Teori Belajar Humanistik}

Adapun kelebihan dan kekurangannya dari teori belajar humanistik adalah sebagai berikut :

\section{Kelebihan teori belajar humanistik}

a. Mengedepankan akan hal-hal yang bernuansa demokratis, partisipatif-dialogis dan humanis

b. Suasana pembelajaran yang saling menghargai, adannya kebebasan berpendapat, kebebasan mengungkapkan gagasan.

c. Keterlibatan peserta didik dalam berbagai aktivitas di sekolah, dan lebih-lebih adalah kemampuan hidup bersama (komunal-bermasyarakat) diantara peserta didik yang tentunya mempunyai pandangan yang berbeda-beda. ${ }^{25}$

\section{Kekurangan teori belajar humanistik}

a. Teori humanistik tidak bisa diuji dengan mudah

b. Banyak konsep dalam psikologi humanistik, seperti misalnya orang yang telah berhasil mengaktualisasikan dirinya ia masih buram dan subjektif

c. Psikologi humanistik mengalami pembisaaan terhadap nilai individualis

d. Siswa yang tidak menyadari dan memahami potensi dirinya akan ketinggalan dalam proses belajar

e. Siswa yan tidak aktif dan malas belajar akan merugikan diri sendiri dalam proses belajar

${ }^{24}$ Baharuddin dan Moh. Makin, Pendidikan Humanistik: Konsep, Teori, dan Aplikasi Praksis dalam Dunia Pendidikan, (Yogyakarta: Ar-Ruzz Media, 2007), hlm. 24.

25 Andi Setiawan, Belajar dan Pembelajaran......, hlm. 91. 
f. Proses pembelajaran lebih difokuskan kepada potensi yang dimiliki siswa, seningga pengembnagan intelektual peserta didik tidak terarah. ${ }^{26}$

\section{E. Guru Sebagai Fasilitator dalam Pembelajaran Humanistik}

Teori humanistik lebih merujuk pada ruh atau spirit selama proses pembelajaran yang mewarnai teknik-teknik yang diterapkan. Peran guru dalam pembelajaran humanistik adalah menjadi fasilitator bagi para siswa, memberikan motivasi, kesadaran mengenai makna belajar dalam kehidupan siswa. ${ }^{27}$

Guru memfasilitasi pengalaman belajar kepada siswa dan mendampingi siswa untuk memperoleh tujuan pembelajaran dengan memahami panduan sebagai seorang fasilitator. Fasilitator sebaiknya memberi perhatian kepada penciptaan awal, situasi kelompok dan pengalaman kelas. Fasilitator membantu untuk memperoleh dan memperoleh tujuan-tujuan perorangan didalam kelas dan juga tujuan-tujuan kelompok yang bersifat umum. Fasilitator mempercayai adanya keinginan dari masing-masing siswa untuk melaksanaan tujuan-tujuan yang bermakna bagi dirinya, sebagai kekuatan pendorong, yang tersenbunyi didalam belajar yang bermakna tadi. ${ }^{28}$

Fasilitator mencoba mengatur dan menyediakan sumber-sumber belajar yang luas dan mudah dimanfaatkan para siswa untuk membantu mencapai tujuan mereka. Fasilitator menempatkan dirinya sebagai suatu sumber yang fleksibel untuk dapat dimanfaatkan oleh kelompok. Fasilitator menerima dan menagggapi ungkapan-ungkapan didalam kelompok kelas baik yang bersifat intelektual maupun sikap perasaan. Bila suasana kelas sudah kondusif, fasilitator berangsur-angsur dapat berganti peran sebagai seorang siswa yang turut berpartisipasi, seorang anggota kelompok. Fasilitator mengambil prakarsa untuk ikut serta dalam kelompok, perasaannya pikirannya dengan tidak menuntut dan juga tidak memaksakan tetapi sebagai

${ }^{26}$ Ibid, hlm. 91.

${ }^{27}$ Husama dkk, Belajar dan Pembelajaran ....., hlm. 119. 
suatu andil secara pribadi yang boleh saja digunakan atau ditolek oleh siswa. ${ }^{29}$

Guru dalam teori belajar humanistik membantu peserta didik untuk memahami secara mendalam dirinya sehingga peserta didik bisa mengembangkan kemampuan yang ada dalam diri mereka. Guru juga mencoba menciptakan pembelajaran yang dapat meningkatkan kemampuan dalam menciptakan, membayangkan, berpengalaman, berintuisi, merasakandan berfantasi. ${ }^{30}$

Menurut Eveline Siregar dan Hartina Nara dalam bukunya Andi Setiawan yang berjudul Belajar dan Pembelajaran, teori ini bersifat eklektik artinya teori apapun dapat dimanfaatkan asal tujuannya untuk memanusiakan manusia. Sebagai contoh teori bermakna Ausubel dan taksonomi tujuan belajar Bloom dan Krathwohl diusulkan sebagai pendekatan yang dipakai oleh aliran kognitif padahal teori ini juga diusulkan dalam aliran humanistik. ${ }^{31}$

\section{F. Implikasi Teori Belajar Humanistik dalam Pembelajaran PAI}

Implikasi teori belajar humanistik yaitu menciptakan pembelajaran yang ideal sehingga setiap pribadi bisa memahami dan mengembangkan diri dengan baik. Untuk menciptakan pembelajaran yang idela maka guru dalam pembelajaran humanistik berperan sebagai fasilitator dan motivator bagi para peserta didik. Peserta didik berperan sebagai pelaku utama yang mehami proses pengalaman belajarnya sendiri sehingga peserta didik memahami potensi dirinya positif dan meminimalkan potensi diri yang bersifat negatif. Tujuan pembelajaran lebih kepada proses belajarnya dari pada hasil belajar. ${ }^{32}$

Implikasi teori humanistik dalam pembelajaran adalah guru lebih mengarah siswa untuk berfikir induktif, mementingkan pengalaman, serta membutuhkan keterlibatan siswa secara aktif dalam proses belajar. Hal ini ditetapkan melalui kegiatan diskusi, membahas materi secara berkelompok.

${ }^{28}$ Ibid, hlm. 119.

${ }^{29}$ Ibid, hlm. 119-120.

30 Andi Setiawan, Belajar dan Pembelajaran....., hlm. 82.

31 Ibid, hlm. 82-83. 
Pembelajaran berdasarkan teori humanistik ini cocok untuk diterapkan pada materi pembelajaran yang bersifat pembentukan kepribadian, hati nurani, perubahan sikap dan analisis terhadap fenomena sosial. ${ }^{33}$

Indikator keberhasilan aplikasi teori humanistik dalam pembelajaran adalah siswa merasa senang, bergairah berinisiatif dalamm belajar dan terjadi perubahan pola pikirperilaku dan sikap atas kemauan sendiri. Siswa diharapkan menjadi manusia yang bebas, berani tidak terikat oleh pendapat orang lain dan mengatur pribadinya sendiri secara bertanggung jawab tanpa mengurangi hak-hak orang lain atau melanggar aturan norma disiplin atau etika yang berlaku. ${ }^{34}$ Aplikasi teori humanistik lebih merujuk pada ruh atau spirit selama proses pembelajaran yang mewarnai teknik-teknik yang diterapkan. Peran guru dalam pembelajaran humanistik adalah menjadi fasilitator bagi para siswa, memberikan motivasi, kesadaran mengenai makna belajar dalam kehidupan siswa.

Adapun penerapan penerapan teori belajar humanistik dalam pembelajaran PAI adalah :

1. Teori humanistik ini cocok untuk diterapkan pada materi pembelajaran yang bersifat pembentukan kepribadian, hati nurani, perubahan sikap dan analisis terhadap fenomena sosial. Jadi teori ini sangat cocok untuk pembelajaran PAI karena pendidikan agama adalah salah satu media untuk pembentukan kepribadian, hati nurani, perubahan sikap daan analisis terhadap fenomena sosial.

2. Dalam pembelajaran akidah akhlak contohnya di dalamnya diajarkan tentang pembentukan kepribadian, hati nurani dll

3. Segi implikasi ini meliputi penerapan teori belajar humanistic dalam proses pembelajaran. Para ahli psikologi humanistic berupaya menggambarkan keterampilan dan informasi kognitif dengan segi-segi afektif, nilai-nilai, dan perilaku antar pribadi. Contohnya, didalam kelas sudah mendapatkan ilmu melalui teori teori yang di sampaikan oleh guru

32 Andi Setiawan, Belajar dan Pembelajaran......, hlm. 89.

33 Husama dkk, Belajar dan Pembelajaran....., hlm. 118-119. 
dan di luar kelas anak-anak mempraktekkan apa yang telah di dapat di dalam kelas pada pertemuan sebelumnya. Karena pada dasrnya pembelajaran PAI bukanlah hanya teori di kelas semata namun harus dengan praktek dan evaluasi kekurangannya dari teori yang sudah di sampaikan di dalam kelas. Maka dari itu sebagai guru PAI harus kreatif dan inovatif agar anak tidak merasa bosan karena sudah di sampaikan teori mengapa harus praktek pula.

\section{Kesimpulan}

Teori belajar humanistik merupakan sebuah konsep yang utuh dalam memandang manusia sebagai mahluk yang unik dan memiliki potensi yang dapat dikembangkan menajadi seorang manusia yang utuh dan sempurna. Teori pembelajaran humanistik merupakan sebuah proses belajar yang berhulu dan bermuara pada manusia, segala sesuatunya disandarkan pada nilai kemanusiaan. Pendekatan sistem pendidikan humanistik menekankan pengembangan martabat manusia yang bebas membuat pilihan dan berkeyakinan. Dalam pembelajaran humanistik peranan guru yang lebih banyak menjadi pembimbing daripada pemberi ilmu pengetahuan kepada siswa, Dalam pembelajaran in siswa dituntut untuk lebih aktif dan semakin meningkatkan potensi dirinya, adapun guru lebih berperan sebagai pemantau, pembimbing dan mengarahkan.

Pada pembelajaran humanistik, belajar dipandang signifikan, jika materi pembelajaran memiliki relevansi dengan kebutuhan siswa. Dalam konteks ini pembelajaran humanistik menekankan pentingnya pemenuhan kebutuhan siswa yang bermuara pada aktualisasi diri. Aktualisasi diri dalam belajar dapat upaya guu mengoptimalkan kemampuan siswa untuk berkreasi dan memperkuat kemampuan dasarnyanya untuk mengembangakan potensi yang dimilikinya. Siswa berperan sebagai pelaku utama yang memaknai proses pengalaman belajarnya sendiri. Ketika siswa memahami potensi diri, diharapkan dapat mengembangkan potensi tersebut.

${ }^{34}$ Ibid, hlm. 119. 


\section{DAFTAR PUSTAKA}

Andi Setiawan, Belajar dan Pembelajaran, (Ponorogo : Uwais Inspirasi Indonesia).

Anzora, Anzora. 2017. “Analisis Kemandirian Siswa Pada Pembelajaran Matematika Dengan Menerapkan Teori Belajar Humanistik”. Jurnal Gantang 2 (2), 99-103. https://doi.org/10.31629/jg.v2i2.200.

Arbayah, Model Pembelajaran Humanistik, Jurnal, Vol 13. No. 2, Desember 2013.

Aunurrahman, Jurnal Pendidikan Konvergensi Edisi Juli 2018.

Budi Agus Sumantri dan Nurul Ahmad, Teori Belajar Humanistik dan Implikasinya Terhadap Pembelajaran Pendidikan Agama Islam, Jurnal UIN Sunan Kalijaga Yogyakarta, Volume 3 Nomor 2 September 2019.

Husama dkk, Belajar dan Pembelajaran, (Malang : UMM Press, 2018).

Iskandar, Implementasi Teori Hirarki Kebutuhan Abraham Maslow Terhadap Peningkatan Kinerja Pustakawan, Jurnal, Vol. 4 No. 1, Januari -Juni 2016.

Ivancevich dkk, Perilaku dan Manajemen Organisasi, (Semarang: Erlangga, 2006).

Jamil Suprihatiningrum, Strategi Pembelajaran: Teori dan Aplikasi, (Yogyakarta: Ar-Ruzz Media, 2013).

Jhon W. Santrock, Psikologi Pendidikan (Jakarta: Salemba Humanika, 2009).

Khusnul Mualim, Gagasan Pemikiran Humanistik dalam Pendidikan (Perbandingan Pemikiran Naquib al-Attas Dengan Paulo Freire), Jurnal, Universitas Muhammadiyah Yogyakarta. Al-ASASIYYA: Journal of Basic Education Vol. 01 No. 02Januari-Juni 2017ISSN: 2548-9992.

Lefudin, Belajar Dan Pembelajaran Dilengkapi dengan Model Pembelajaran, Strategi Pembelajaran, Pendekatan Pembelajaran dan Metode Pembelajaran, (Yogyakarta : Deepublish, 2014).

Miki Yuliandri. 2017. "Pembelajaran Inovatif di Sekolah Berdasarkan Paradigma Teori Belajar Humanistik” Journal of Moral and Civic Education Vol 1 No 2 (2017) https://doi.org/10.24036/8851412020171264

Mohammad Muchlis solichin. 2018. “Teori Belajar Humanistik Dan Aplikasinya 
Dalam Pendidikan Agama Islam: Telaah Materi Dan Metode

Pembelajaran”. Islamuna: Jurnal Studi Islam Vol 5, No 1 (2018)

http://dx.doi.org/10.19105/islamuna.v5i1.1856

Ranu Nada Irfani. 2017. “Formulasi Kajian Psikologis Tentang Teori-Teori

Belajar dalam Al-Quran dan Hadits”. Ta’dib : Jurnal Pendidikan Islam Vol 6, No 1 (2017) https://doi.org/10.29313/tjpi.v6i1.2319

Sri Esti Wuryani Djiwandono, Psikologi Pendidikan, (Jakarta: PT. Gramedia Widiasarana Indonesia, 2006).

Suharsimi Arikunto, Prosedur Penelitian Suatu Pendekatan Praktek, (Jakarta: Rineka Cipta, 1997).

Supratinya, Mazhab Ketiga Psikologi Abraham Maslow Oleh Frank G. Goble, (Yogyakarta: Kanisius, 2010).

Thunsan Hakim, Belajar Secara Efektif, (Yogyakarta: Niaga Sadaya). 
